IZA DP No. 7332

Making it Work: The Mixed Embeddedness of Immigrant Entrepreneurs in New Zealand

Trudie Cain

Paul Spoonley

April 2013 


\title{
Making it Work: The Mixed Embeddedness of Immigrant Entrepreneurs in New Zealand
}

\author{
Trudie Cain \\ Massey University \\ Paul Spoonley \\ Massey University \\ and IZA
}
Discussion Paper No. 7332
April 2013

\author{
IZA \\ P.O. Box 7240 \\ 53072 Bonn \\ Germany \\ Phone: +49-228-3894-0 \\ Fax: +49-228-3894-180 \\ E-mail: iza@iza.org
}

\begin{abstract}
Any opinions expressed here are those of the author(s) and not those of IZA. Research published in this series may include views on policy, but the institute itself takes no institutional policy positions. The IZA research network is committed to the IZA Guiding Principles of Research Integrity.

The Institute for the Study of Labor (IZA) in Bonn is a local and virtual international research center and a place of communication between science, politics and business. IZA is an independent nonprofit organization supported by Deutsche Post Foundation. The center is associated with the University of Bonn and offers a stimulating research environment through its international network, workshops and conferences, data service, project support, research visits and doctoral program. IZA engages in (i) original and internationally competitive research in all fields of labor economics, (ii) development of policy concepts, and (iii) dissemination of research results and concepts to the interested public.
\end{abstract}

IZA Discussion Papers often represent preliminary work and are circulated to encourage discussion. Citation of such a paper should account for its provisional character. A revised version may be available directly from the author. 


\section{ABSTRACT \\ Making it Work: The Mixed Embeddedness of Immigrant Entrepreneurs in New Zealand}

In seeking economic immigrants, especially those who are skilled, entrepreneurial and with capital to invest, a settler country such as New Zealand has assumed that national and city labour markets/economies will gain by adding to the human capital pool as well as creating new 'economic' activities of various sorts. Economic participation, both as labour but also as typically small business owners, often reflects the nature of mixed embeddedness (Kloosterman and Rath 2003) and especially the relational embeddedness (Portes, cited in, Vertovec 2009) of particular immigrant groups. This is most apparent in relation to social and economic networks, the deployment of human capital, immigrant engagement strategies and transnational activities. Using the concept of mixed embeddedness, this paper examines the strategies and outcomes for migrant entrepreneurs from the People's Republic of China, the Republic of Korea, India, South Africa and the United Kingdom, drawing upon a largely qualitative analysis of immigrant employers from these groups.

JEL Classification: J15, J24, J39

Keywords: migration, relational embeddedness, structural embeddedness, mixed embeddedness, New Zealand, immigrant entrepreneurs

Corresponding author:

Trudie Cain

Massey University

Private Bag 102904

North Shore

Auckland 0745

New Zealand

E-mail: t.cain@massey.ac.nz 


\section{Introduction}

Immigrant recruitment, including those immigrants with business experience, has been central to New Zealand's nation-building project. However, unlike the two most obvious comparator countries - Canada and Australia - New Zealand has historically relied almost exclusively on British and Irish migrants (Spoonley and Bedford 2012). This changed with the arrival of significant numbers of migrants from the Pacific from the 1960s, although this involved primarily labour (often semi or unskilled), rather than business migration. It was not until the immigration policy changes of 1986/87 that New Zealand adopted the points (and ethnically-neutral) system of Canada and Australia, resulting in much more diverse compositional flows and a primary focus on skilled and business (economic) migration. Perhaps the only significant policy difference concerns the emphasis given to biculturalism in the New Zealand context, as opposed to the (evolving) multiculturalism of Australia and Canada (Larner 2006).

Simultaneously, policy development, especially settlement policies and economic development, has been shaped by neo-liberal assumptions and policy influences (Spoonley and Meares 2011; Spoonley 2003; Skilling 2005; Skilling 2010; Lewis, Lewis, and UnderhillSem 2009; Lewis 2009). Consequently, the emphasis is on globally recruiting human capital that can fill gaps in the labour market and contribute to an individualised entrepreneurialism. In this regard, there have been few differences in approach between the three countries. However, in New Zealand's case, the assumptions of a local neo-liberalism are most apparent in what happens to migrants post-arrival. It is assumed that migrants have been selected for their education, skills and experience and therefore the state, in whatever manifestation (local or national), is not required to play any major role in settlement. Immigrants are "competitive responsibilised and entrepreneurial selves" (Lewis, Lewis, and Underhill-Sem 2009, p.167) who are able to exploit the markets that neo-liberalism promotes. As a result, the settlement 
of immigrants is largely left to their own agency and the opportunities (and barriers) of the marketplace, notably in relation to labour market success or small business establishment.

In reality, the austerity of this approach in its early and most minimalist form (19862000) was unsustainable, and the New Zealand government moved to resource settlement in various ways after 2000. But budget cuts from 2009 significantly reduced even these modest support schemes (e.g. the cuts to Adult and Community Education which stripped out English language provision for migrants) and the level of support for immigrants was always significantly less than that provided in Australia or Canada. For example, there is no equivalent to the $\$$ Can3000 per immigrant provided to aid settlement in Canada, nor are there formalised programmes on language acquisition, understanding the local cultural or business environment or how to access key services offered in New Zealand, except on a fee-basis or as an ad hoc local initiative, often offered by Non-Government Organisations or business associations. The prevailing ethos emphasises personal responsibility and privileges the market.

Many immigrants arriving in New Zealand are unable to enter the labour market at levels commensurate with their qualifications and skills (Department of Labour 2009). In the Auckland context in particular, this has led to the establishment of small or medium-sized businesses, sometimes as a default option, often serving the needs of migrant communities (Spoonley and Meares 2011). In some areas, and within some ethnic groups, these developments have led to the rise of ethnic precincts - the concentration of economic activities involving one immigrant group or another. Chinese-dominated precincts such as the purpose-built Meadowlands in East Auckland, organically developed Northcote shopping centre on Auckland's North Shore (see Spoonley and Meares 2011) and the strip retail development of Dominion Road in central Auckland (see Cain et al. 2011) are key examples. The ethnic and immigrant character of these rapidly growing business clusters has been a 
significant development in the last decade (particularly in Auckland) and reflects the reliance of some migrant groups on ethnic-specific networks.

These developments have been backgrounded by a neo-liberal policy environment which continues to privilege market forces; which encourages business establishment, especially small and medium businesses that dominate a service economy; and which gives prominence to entrepreneurial activity. While a Labour-led government in the early 2000s did seek to provide limited forms of market intervention, the election of the conservative National-led government in 2008 quickly saw the reversal of such intervention and the return to immigrant self-reliance. New Zealand more generally is "emerging as one of the world's most entrepreneurial countries" (Frederick 2004, p. 7) although this is often defined by the self-employed who comprise 10.5 per cent of the workforce (with business activities concentrated in small and medium-sized enterprises) (Ministry of Economic Development 2011). ${ }^{1}$ There is a long and sustained history of migrant entrepreneurship in New Zealand (see, for example, Ip 2003). However, social capital and the available networks of business owners are crucial for the continued success of migrant business enterprises (Cooke 2007), especially in early stage migrant settlement. With this in mind, we have considered the existence and efficacy of ethnic entrepreneurs' social networks given their recent arrival, and possible lack of effective broader (non-migrant) networks to support their business practices.

\section{Structural, relational and mixed embeddedness}

The aim of this article is to empirically examine the extent to which recently-arrived migrants, who have established themselves in a business post-arrival, are embedded in broader networks. The concept of embeddedness is not new. It was first introduced by

\footnotetext{
${ }^{1}$ Ninety-seven per cent of all enterprises in New Zealand employ 19 or fewer staff, accounting for 40 per cent of the economy's total output and 31 per cent of New Zealand's employees (Ministry of Economic Development 2011).
} 
Granovetter $(1973 ; 1983)$ who drew on the term in an attempt to capture a middle ground between economic theory that under-socialises behaviour, and much of the existing sociological theory that over-socializes behaviour (Granovetter 1985). Put another way, Granovetter argued that economic rationality must always be considered as embedded within social relationships and that this insight is often overlooked in sociological analyses.

Applied to the field of migration studies, there has been a considerable body of work that has considered and extended this concept (see Vertovec 2003; Rath 2002). For example, with regard to the development of ethnic precincts, Waldinger, Aldrich and Ward (1990) suggested that two key factors need to be considered in order to understand ethnic business co-location: first, ethnic and socio-cultural explanatory factors, essentially the decisions made by immigrants and their communities; and second, the external political and economic factors that shape experience. Kloosterman and Rath (2003) expanded this with an approach that stresses the mixed embeddedness of immigrant businesses. Their analysis combines the embeddedness of migrants in specific ethnicised networks, relational embeddedness in Portes' terms (Vertovec 2009, p. 37) with the role and impacts of broader structures. Relational embeddedness provides certain advantages, notably "reduce[d] transaction costs by eliminating formal contracts [and] ... privileged access to vital economic resources" (Pang and Rath 2007, p. 200). The regulatory and opportunity structures contextualise the agency of migrants and the economic possibilities or barriers. In brief, structural embeddedness refers to the integration of migrants into the wider society and labour market, while relational embeddedness is the extent to which communities and networks act as a source of social capital to the migrant (Portes 1998; Kloosterman, van der Leun, and Rath 1999). Taking account of these two (interconnected) elements ensures that the varied vertical and horizontal linkages between immigrants and the wider communities within which they live are more adequately recognised (Vertovec 2009, p. 37). 
The relational embeddedness of migrants plays an important role in settlement, as existing familial and community networks, underpinned by cultural values, a shared language and various forms of solidarity, provide support and guidance for newly arrived migrants in a situation that is unfamiliar. However, the neo-liberal regulatory and policy environment tends (perhaps unwittingly) to privilege this relational embeddedness. A neo-liberal political and economic climate encourages the agency of the individual as an expression of a market in action; business establishment and entrepreneurial activity to meet market demand is given as evidence of the 'obvious' benefits of a market economy; and the virtues of self-reliance and independence are venerated while dependence on state provision (except in the most dire cases) is deplored. In this sense, the entrepreneurial immigrant, who invests personal resources into business establishment, and who does not require state intervention and support, is the archetypal free market agent. The social and cultural networks of immigrant communities, combined with an interest in small business establishment, make the relational embeddedness of immigrants a significant factor in decisions about what sort of business to establish and where to locate that business. In the decades since the introduction of a neoliberal approach to economic management (dating from 1984 in New Zealand), immigrant business establishment has reflected internal, ethnic dynamics combined with the external emphasis on market-driven decision-making.

\section{Methodology}

This paper draws on empirical research carried out by the Integration of Immigrants Programme (IIP). The objectives of the IIP are to quantify and explain differences in economic outcomes between migrants and the New Zealand-born population using econometric modelling and to better understand the processes involved in migrant economic settlement using both quantitative and qualitative research methodologies. This article draws on survey data generated from qualitative interviews with migrant employers residing in 
Hamilton and Auckland that were carried out between 2009 and 2010 (see Meares et al. 2010a, 2010b; Meares et al. 2011; Watson et al. 2011; Lewin et al. 2011, for full reports on each migrant group).

In-depth, face-to-face interviews lasting 60 to 90 minutes were held with a total of 67 employers who met the following criteria: born in either the People's Republic of China (20), the Republic of Korea (20), the Indian subcontinent (7), South Africa (13) or the United Kingdom (7); granted permanent residence in New Zealand from 2003 or later; Goods and Services Tax-registered (i.e. were required to pay tax on business activities); and had at least one employee (paid or unpaid, full or part-time). The interview schedule gathered comprehensive demographic information and also included a series of open-ended questions that asked about the participants' experiences of settling in New Zealand and establishing a business. Participants were recruited through the research team's existing networks in the community; immigrant organisations, consultants and support personnel; hospitals and other health organisations; community and business websites; and schools and training institutes. Interviews were recorded, relevant text transcribed and thematically analysed with the assistance of NVivo.

\section{The business of mixed embeddedness: Five groups compared}

In the following, we turn our attention to the empirical results of the survey carried out with business owners. After providing a brief overview of each of the migrant groups that are the focus of this article, we explore the nature of mixed embeddedness to examine the extent to which these migrant groups utilise personal, business/professional and social networks, and implications for business practice and settlement.

Since the turn of the century, New Zealand has experienced increased immigration from China. Between the 2001 and 2006 censuses, the number of migrants from China 
doubled to 53,694; they now comprise just over 55 per cent of the ethnic Chinese population of Auckland (Meares, Cain, and Spoonley 2011; Meares et al. 2010a). There is evidence of considerable downward occupation mobility for migrants arriving from China (Statistics New Zealand 2010; Henderson 2004). Perhaps as a result of thwarted labour market entry, many Chinese migrants are self-employed and Chinese-owned and operated businesses are obvious throughout Auckland.

Beginning in the late 1980s, the number of immigrants arriving in New Zealand from the Republic of Korea has increased substantially. Between 1986 and 1996, Koreans were the fastest growing Asian group in New Zealand and by the last census in 2006, there were 30,792 Koreans living in the country. Two-thirds of New Zealand's Koreans live in Auckland, the majority in the middle-class suburbs of the North Shore (Meares et al. 2010b). There is some evidence of downward occupational mobility in the transitions made between Korea and New Zealand and many move into fields quite different from their pre-migration roles.

Although Indians have been arriving in New Zealand for the last 150 years, numbers remained relatively low until the mid-1980s. Between 1986 and 2001, the Indian population in New Zealand more than quadrupled in size and, by the last census in 2006, there were 104,600 people of Indian ethnicity living in the country. ${ }^{2}$ Over two-thirds of New Zealand's Indians live in Auckland, the majority in and around the suburbs of Avondale, Lynfield, Hillsborough and Sandringham (Lewin et al. 2011). With regard to employment, there is evidence of some downward occupation mobility.

\footnotetext{
${ }^{2}$ Given the increased importance of Asia as a source of immigrants to New Zealand, our research focused on those immigrants from the Indian sub-continent rather than Indo-Fijian immigrants. However, census data often fails to differentiate between these two groups. Consequently, unless otherwise stated, all census data cited in the report reflects those of Indian ethnicity in its broadest sense.
} 
South Africans began arriving in New Zealand during the apartheid years but numbers remained relatively low until the 1990s. By 2001, they comprised the fifth largest migrant group in New Zealand and numbered 41,676 at the last census in 2006. Migration to New Zealand during the last two decades has largely been a result of 'push' rather than 'pull' factors: political instability, violence and crime; positive discrimination workplace policies; and a perceived drop in the quality of education and infrastructure in South Africa are cited by migrants as motivations for coming to New Zealand (Pernice et al. 2009). Although South Africans have settled all over New Zealand, the highest proportions have chosen to live in Auckland (Meares et al. 2011). There is less evidence of downward occupation mobility for those migrants arriving from South Africa (compared to other source countries, particularly those from Asia), and indeed, our research demonstrated that the choice to establish a business was more often based on a strong motivation to be autonomous in their working lives.

Historically, the largest proportion of immigrants arrive in New Zealand from the United Kingdom and Ireland (Spoonley and Butcher 2009). The 2006 Census registered 244,800 United Kingdom-born migrants in New Zealand. Although residing throughout the country, the greatest concentrations can be found in Auckland (with clusters in the residential areas of Rodney/North Shore, Greenhithe, Waiheke Island, Howick, Botany Downs and Beachlands) and the lower North Island, especially on the Kapiti Coast (Watson et al. 2011). There is little evidence of downward occupational mobility for migrants arriving from the United Kingdom (Stillman and Maré 2009) and reports from our own research indicate that decisions to start businesses were often positively framed around personal satisfaction, leisure and lifestyle. 


\section{Mixed embeddedness at work}

We asked participants from each of the immigrant groups about the people or organisations that helped them to establish their businesses in New Zealand. We offered a number of suggestions, including a range of business/professional and social services, as well as friends and family located either in New Zealand or overseas. Many participants indicated that New Zealand-based friends and family were most helpful. Chinese participants were heavily reliant on New Zealand-based friends and family, including parents and adult children, when establishing their businesses $(85 \%$, or 17 of the 20 participants, relied on such support). New Zealand-based friends and family were also the most common source of business start-up assistance for Korean and South African participants (60\% and 69\% respectively). Although two of the Indian participants commented that no one provided them with business establishment assistance, nearly half noted the assistance of their New Zealandbased family and friends. Participants' high level of reliance on family and friends is not unusual for new migrants and suggests that social/relational networks play an important role in contributing to settlement and business start-ups. Although the question we asked did not specify whether New Zealand-based friends were co-ethnics or not, the detailed responses provided by participants suggest that this was often the case:

I have a few good mates... The thing is that most of them are actually English ... mostly they are English, Irish, Scottish, and I think why that is, is that we are all in the same boat ... when you are in the same boat it is easier. (British business owner)

In contrast to those heavily reliant on family and friends to establish their business enterprises, only one British participant mentioned that friends and family in New Zealand had been helpful. Instead, this group were more typically reliant on business or professional groups to assist them. More specifically, they indicated reliance on groups such as the 
Auckland Chamber of Commerce, Department of Labour, Immigration New Zealand, bank managers and accountants, local council and business associations. This disinclination to draw significantly on social support and networks perhaps reinforces the frequently-stated view that migrants from the United Kingdom do not find life in New Zealand substantially different from the life they have left behind and, consequently, establishing themselves (in business or otherwise) is attained with relative ease.

Interestingly, although over two-thirds of South African participants did call on New Zealand-based friends and family when setting up their businesses, this group, like the British, also relied most heavily on non-ethnic structural business support, including bank managers or accountants, professional/business associations or organisations, or business support programmes such as the Kiwi Ora programme. However, their reasons for doing so appeared to be quite different from British migrants. South African migrants appeared to recognise and acknowledge their limited or non-existent social/relational networks in their new and unfamiliar environment post-migration:

It is important who you know in this country... I mean you come in here and you don't know anybody. I mean, I am afraid ... you are just not going to get anywhere ... when you spent 15 years doing the same thing ... you have a network, so if you need someone you can ring them and say 'I need this.' They might say, 'Oh, I can't help you but I know someone who can.' That I have really struggled with. (South African business owner).

For some, limited relational embeddedness post-migration encouraged them to take advantage of external professional networks. These structural networks are located within formalised structures of local business practice and, as such, they allow those who utilise them to embed their prospective business practice within a broader New Zealand operational business milieu (they do not rely on co-ethnics for information, supply or as 
customers/clients). In doing so, they assist in the integration of ethnic entrepreneurs into the local business environment.

\section{Maintaining a business - staffing}

Social or relational connectivity was also important for locating staff to work in the business. Among the five migrant groups of business owners, there were distinct differences but also similarities in those they employed in their enterprises. Those participants who arrived from Asia were most likely to employ co-ethnics. All of the Chinese participants, and 85 and 60 per cent respectively of the Indian and Korean participants, employed at least one person who they identified as sharing the same ethnicity. A very different picture emerged for those born in South Africa and Britain. Only a relatively small number (two of the 13 participants) of South African participants employed other South Africans. Indeed, even in cases where co-ethnics were employed, it seemed incidental to their business operations rather than a central feature of their business strategy; the ethnicity of their employees did not seem to matter:

It is completely bizarre because ... out of 14 staff that are there, we have three Kiwis. The rest are something else ... South African, English, Swiss, Zimbabwean, Scottish ... truly United Nations. (South African business owner)

With regard to British participants, it is difficult to say with any accuracy how many employed others born in Britain. Only one participant was certain he employed at least one British employee. Typically, others were very vague about the ethnicity of those they employed and, like South African participants, also indicated that ethnicity was not an issue:

My workers, so far we've employed two Kiwis and an Australian and we're British. Generally I've had a good mix. Right now I have, I guess they'd call themselves Kiwis, all four of them but two of them are Croatian originally. I've 
had South Africans, Europeans and obviously Kiwis as well so a fairly good mix. No Indians and no French or anything like that or Asian. (British business owner)

In this quote, the ethnicity of past and present employees is far from fixed. Indeed, the employer alludes to the fluidity of ethnicity and the lack of distinct boundaries around what constitutes ethnic identity. Perhaps what is most striking, however, is his reference to a "good mix". Certainly, the range of ethnic identities is far from homogenous. However, neither does it reflect a truly heterogeneous ethnic group; they are all of European descent and each share a common language - English. Although the ethnicities of his employees are not necessarily a direct reflection of his own, they do reflect his socio-cultural frame of reference.

We also asked participants about whether they employed family members (both paid and unpaid) in their businesses. We found that it was not uncommon among each migrant group for family members, mostly wives, to work in the business in either paid or unpaid capacities. Of the Chinese business owners, twenty per cent had between one and three paid employees who were family members (wives in $75 \%$ of cases) while one-quarter of Korean business owners' paid employees were family members, including wives (40\% of cases), daughters (20\% of cases) and sons ( $40 \%$ of cases). Although the Indian business owners were equally likely as the Korean business owners to employ other co-ethnics, they were far less likely to employ family members in a paid capacity (only one participant did so); the majority of their paid employees were from outside the family. Nearly half of South African and British participants also employed some paid family members (between one and four employees). This typically included wives and husbands, and in the case of South African participants, also children and other extended family.

Paid familial involvement in the business is indicative of formal relational networks. They are formal in that as a paid employee, the family member will (mostly) be registered 
with the tax department and will be part of the legitimate and transparent cost of running the business. Kloosterman, van der Leun and Rath (1999, p. 7) argue that "there is no sharp demarcation between 'the' formal and 'the' informal economy". In the relationally embedded nature of employing family members in a paid capacity, the lack of distinction becomes pronounced. Although the employment itself might operate within formal economic principles, participants often reported a degree of informality with regard to the kinds of activities performed in the role. For example, for those Asia-born participants (especially Chinese and Korean) who reported poor English-language proficiency, paid family members who could speak English often took on the role of translator between the business owner and their suppliers, other staff and their customers.

Not all of the family members working in the participants' businesses were paid. Of the Chinese business owners, 45 per cent had a family member working without wages or salary, including wives and husbands (44\% and $20 \%$ of cases respectively), and fathers and sons. Similarly, half the Korean participants had an unpaid family member in their employ, mostly wives or husbands but also, to a lesser extent, children. Of the Indian employers, 71 per cent had a family member, mostly wives, working in the business without wages or salary. Nearly one-third of South African business owners reported that they employed family members without pay, less than those business owners from Asia but still significant. British participants were quite different in this regard. Although, as discussed, they employed family on a formal paid basis, none reported having unpaid family members in their employ.

With regard to staffing, Asia-born migrants were particularly reliant on co-ethnic relational networks, or more particularly, familial networks, to maintain their business operations. Co-ethnic networks were less vital for those arriving from South Africa and Britain. That said, for all migrant groups, relational embeddedness (manifested as a degree of reliance on familial resources) resulted in the employment of family members to support 
business enterprises. For each of the five migrant groups, women were more typically employed in the family business, both paid and unpaid, and in formal and informal settings. The gendered nature of participants' familial embeddedness and the potential vulnerability for migrant women employed (paid or otherwise) within family businesses, speaks to the structural "socio-economic and politico-institutional environment" of the labour market (Kloosterman, van der Leun, and Rath 1999, p. 254) in which businesses are situated.

\section{Maintaining a business - suppliers}

Suppliers were often cited by participants of each migrant group as crucial to the success of their businesses. However, there were (again) distinct differences between the suppliers of Asian participants and the suppliers of South African and British participants. For those arriving from China, Korea and India, pre-existing co-ethnic networks that were located in the country of origin continued to be important when establishing a business in New Zealand post-migration. All of the Chinese participants had at least one Chinese (and Chinese speaking) supplier and, indeed, a few business owners dealt exclusively with Chinese-speaking suppliers. Furthermore, Chinese participants were highly likely to travel to China for business purposes $(50 \%$ of Chinese participants reported travelling internationally to support their businesses, and $90 \%$ of them travelled to China).

Nearly half of Korean and Indian participants had at least one supplier from their country of origin. A key difference between these two migrant groups and the Chinese participants is that they were more likely to also have suppliers from other countries, including New Zealand. Over half of Korean participants had at least one 'Kiwi' supplier and one-third had at least one Chinese supplier. Similarly, 85 per cent of Indian participants also had 'Kiwi' suppliers alongside co-ethnic suppliers. 
There were a number of reasons why Chinese, Korean and Indian participants chose predominantly co-ethnic suppliers. The first reason centred on the supply itself and included: the fair price of goods; a stable source of supply; and the fact that the majority of participants were operating businesses that sold co-ethnic food and required a range of specialist ingredients:

I need to learn any new dish in China so I can provide it to my customers here as soon as possible. The other reason is that some materials I can only get from China, so sometimes I need to import products. (Chinese business owner) My networks in Korea deal with the sending part of my business, such as custom clearance and delivery ... Their job is to communicate with my customers in Korea. Above all, they are the source of my income. That's why they are very important to me. (Korean business owner)

Second, remaining relationally embedded within networks of co-ethnic suppliers permitted business owners to conduct business in their native language. This was reported as particularly important for those who had arrived from China and Korea because all of the Chinese participants and nearly half of the Korean participants spoke their native language with at least one of their suppliers. From a Chinese business owner:

The reason for using Chinese suppliers is that it is easier for me to communicate with them. I don't have many choices in supplier so I must keep a good relationship with them. (Chinese business owner) 
For Indian, South African and British participants, English language proficiency was not a concern. All participants could speak English, and did speak English with most of their suppliers, irrespective of their business type. ${ }^{3}$

In contrast to participants of Asian descent, South African participants were most likely to have their goods supplied by 'Kiwis'; 70 per cent had at least one Kiwi/Pākehā supplier. In much the same way as British participants were uncertain about their employees' ethnic backgrounds, they were also unsure and somewhat vague when discussing the ethnicity of their suppliers. Indeed, it was not uncommon for the question to remain unanswered. However, some provided a narrative in response to the question which often underlined their uncertainty:

I think they're mainly Kiwi. Our main supplier is ... down the road. Most of the chaps there are Kiwi ... Some of them Māori Kiwis. All Europeans from the UK. I do deal, not directly, with Pakistan and India ... It's made over there and I buy it direct. The one I used to use a lot was originally from England, he's been here about forty years so called himself a Kiwi. (British business owner)

The relational embeddedness of Chinese and Korean business owners in particular demonstrates the extent to which their lives as ethnic entrepreneurs are truly global (see Wong and $\mathrm{Ng}$ 2002, for evidence of transnational networks in a Canadian setting). However, the ongoing connectivity with suppliers in their country of origin is also indicative of structural embeddedness. Indeed the interconnections between relational and structural embeddedness in this instance, cannot be separated. Goods purchased from China, for example, are often chosen because of their 'Chinese-ness' and because they fill an important need in the New Zealand market place (often meeting the needs of other co-ethnics). In

\footnotetext{
${ }^{3}$ It should be noted that this does not indicate that the participants spoke only English. In fact, one-third of South African participants also reported speaking Afrikaans with their suppliers.
} 
contrast, participants from South Africa and Britain, and to a lesser extent India, spoke little of the ongoing connectedness between their homeland and their business activity with regard to suppliers. This was partly because the nature of their businesses were less likely to be ethnicity-specific while Chinese and Korean businesses were often targeted toward an 'ethnic market' - in itself an indication of the structural and relational embeddedness of these groups.

\section{Maintaining a business - customers}

So far we have discussed issues of staffing and securing supplies for participants' businesses. In the following, we consider the mixed embeddedness of participants with regard to customers. As with staff and suppliers, participants originating from Asia were more likely to rely on co-ethnic customers. This was especially so for those born in China and Korea (90\% and $85 \%$ respectively had co-ethnic customers). For those born in South Africa and India, just over half reported having co-ethnic customers and for British participants, just over one-quarter reported having customers who were also born in Britain. That said, there seemed to be significant qualitative differences in the ways participants thought about the ethnicity of their customers. What came across most strongly was the proportion of South African participants (one-quarter) and British participants (nearly half) who stated that their customers came from a range of ethnicities, including a number of ethnic groups outside of the particular interests of our project:

In the main, Kiwi, English or South African but we do obviously have some Korean, Chinese ... Japanese ... a couple of Filipinos as well. Indians, now you're going to ask me whether they're Fijian? One of them comes from

Nottingham. We've got Eastern Europeans. (British business owner)

Our customers ... I certainly have European-descent Kiwis, a fair number of Maori and ... Asian as well, Taiwanese and Chinese, ... quite a few Asian ... 
South Africans, yes there is a significant number of South African people now. (South African business owner)

A further important distinction when considering the ethnicity of participants' customers is the language spoken; business largely took place within an English-speaking environment. Despite fairly high numbers of South African, Indian and British participants having co-ethnic customers, the main language spoken with those customers was English (although Indian participants did not always speak English with customers, it was the preferred language). Given English is the primary language spoken in New Zealand, this provides a broader customer base over those who have not attained English language proficiency.

Those participants for whom English was a second language and, as a result, were not especially proficient English speakers, relied heavily on relational networks in order to communicate effectively in the business environment. This was particularly important when communicating with customers. For both Chinese and Korean business owners, hiring bilingual (Mandarin-English and Korean-English) speakers and enlisting the help of Englishspeaking family or friends was an important strategy used to manage their own difficulties with English. Indeed, hiring English-speaking staff was crucial to their business success:

My English is very bad so I must hire employees who speak good English. (Chinese business owner)

The hardest obstacle was speaking in English. I solved this problem by hiring a Korean manager who could speak fluent English. (Korean business owner)

These bilingual co-ethnic linguistic networks extend the social and structural embeddedness of Chinese and Korean business owners by extending their claim on the marketplace. Although they noted the importance of being able to able to speak Chinese and 
Korean with their co-ethnic customers $(90 \%$ and $70 \%$ of Chinese and Korean participants had Chinese and Korean speaking customers respectively), they also stressed the importance of speaking English with customers:

The owner needs to speak good English. There are a lot of situations where the owner has to communicate with others in English. Most of my customers speak English. (Chinese business owner)

English was often framed as a universal language of sorts that could also be used to communicate with customers from other migrant communities. English language proficiency was constructed as a primary strategy for extending and strengthening a clientele and targeting 'mainstream' customers in addition to co-ethnics. Indeed, when asked what advice they would give to other migrants starting businesses in New Zealand, Chinese and Korean participants typically emphasised the need for English language proficiency above other factors.

While Chinese and Korean participants relied heavily on bilingual relational networks to meet the needs of their customers, South African and British participants emphasised structural aspects. Typically, this involved working hard to understand the local business (and socio-cultural) environment. When Indian, South African and British participants were asked what advice they would offer newly-arrived migrant entrepreneurs, the answer typically centred on understanding the local environment. For example, one Indian business owner recommended that instead of going into business straight away, newly arrived migrants should "get a job first and learn the Kiwi way - the culture, the work ethic". In addition to learning about the cultural practices of their adopted country, these migrant groups also stressed the importance of learning about the business environment. Overall, they emphasised the importance of understanding local market conditions; meeting professional registration criteria and compliance requirements; and understanding the legal frameworks for operating a 
business in New Zealand. Acting on their own advice, 42 per cent of Indian participants, 46 per cent of South African participants and all of the British participants belonged to a business or professional organisation (compared with the Chinese and Korean participants, only one of whom had joined a local business association from each migrant group). Indeed, many belonged to multiple organisations, and while a few interviewees claimed to receive little direct benefit from their memberships, the majority claimed that they enjoyed their involvement and received considerable benefits from their participation:

The [professional] association helped me with a lot of information about doing the exams to register here. (South African business owner)

It seems that for South African and British participants, and to a lesser extent Indian participants, understanding the structuring framework of business operations in a new country were deemed more important than relying on co-ethnic networks as a customer-base. With regard to mixed embeddedness, the structural elements figured as more important.

\section{Conclusion}

Following Kloosterman and Rath (2003), we argue that mixed embeddedness (that is, both structural and relational embeddedness) is useful for making sense of the five migrant groups' experiences of establishing a business on arrival in New Zealand. Our research has shown that the relational embeddedness of migrant entrepreneurs, combined with the structural environment (especially the neo-liberal approach towards immigrant settlement and the privileging of business establishment) produce quite different outcomes for immigrants from Asia compared to those from Britain or South Africa.

Different forms of embeddedness arise for different migrant groups as they operate within the New Zealand business environment. Chinese and Korean business owners are more likely than other migrant groups to rely on co-ethnic networks for capital, supplies and 
information, labour, and for a customer-base. Although we did not ask explicitly about the degree of trust embedded within these networks, it would appear that, like Fong et al. (2007) found in their study of ethnic entrepreneurs in Toronto, this was an important factor in establishing and maintaining their business enterprises. Co-location with co-ethnics also facilitated this process, permitting business owners to exploit the ethnic networks in which they were situated (see also Spoonley and Meares 2011).

South African, British and Indian participants faced challenges as they sought to establish themselves in business in New Zealand. However, their English language proficiency (in particular) as well as their greater familiarity with business practices in New Zealand meant they were less reliant on co-ethnic relational networks. Instead, these groups (especially South African and British participants) emphasised the need to attain local knowledge pertaining to both business practice and local culture; as part of their strategy for business establishment, they invested more in understanding the structural elements of the business environment, including the political and regulatory framework.

A key distinction among the five migrant groups was the role of formal and informal business practices, particularly with regard to familial networks. Renooy (1990, cited in Kloosterman and Rath 2003, p. 5) describes informal production activities as activities aimed at producing a positive effect on income (for the person executing the activities and/or for the person receiving the results), for which the terms of legislation and regulations (planning requirements, social security legislation, collective labour agreements, and the like) applicable to the activities are not being met.

Familial networks were important to each of the five migrant groups in assisting in the success of their enterprises. However, for British and South African participants, these 
familial networks were formalised and embedded within the structural organisation of their businesses. In contrast, for Chinese, Korean and Indian participants, the delineation between structural and relational/familial embeddedness was not as distinct. A key informal economic practice involved hiring unpaid family members to indirectly boost productivity. As such, these relational networks played a vital role in the success of the enterprise. 


\section{Acknowledgements}

This paper draws on research and publications from the Integration of Immigrants Programme (IIP), and we would like to acknowledge the contribution of our colleagues, Carina Meares, Robin Peace, Elsie Ho, Jacques Poot and Richard Bedford; and the New Zealand Ministry of Science and Innovation (formerly the Foundation for Research, Science and Technology) who funded the IIP (2007-2012). Most importantly, we wish to thank all of the research participants who contributed so generously to this project. 


\section{References}

Cain T, Meares C, Spoonley P, Peace R (2011) Halfway house: The Dominion Road ethnic precinct. Massey University/University of Waikato, Auckland

Cooke, P (2007) Social capital, embeddedness, and market interactions: An analysis of firm performance in UK regions. Review of Social Economy 65(1):79-106. doi: 10.1080/00346760601132170.

Department of Labour (2009) New faces, new futures: Findings from the Longitudinal Immigration Survey: New Zealand (LisNZ) - Wave One. IMSED Research, Wellington

Fong E, Chen W, Luk C (2007) A comparison of ethnic businesses in suburbs and city. City \& Community 6(2):119-136

Frederick H (2004) Unitec New Zealand's Centre for Innovation \& Entrepreneurship Research Report Series. In The Unitec Global Entrepreneurship Monitor 2003/2004: Toward high growth enterprise in New Zealand. Unitec New Zealand, Auckland

Granovetter M (1973) The strength of weak ties. American Journal of Sociology 78:1360-1380

Granovetter M (1983) The strength of weak ties: A network theory revisited. Sociological Theory 1:201-233

Granovetter M (1985) Economic action and social structure: The problem of embeddedness. American Journal of Sociology 91(3):481-510

Henderson A (2004) The settlement experiences of immigrants (excluding refugees) in New Zealand: An overview paper completed for the Auckland Regional Settlement Strategy. International Pacific College, Palmerston North

Ip M (2003) Unfolding history, evolving identity: The Chinese in New Zealand. Auckland University Press, Auckland

Kloosterman R, Rath J (2003) Immigrant entrepreneurs: Venturing abroad in the age of globalization. Berg, Oxford

Kloosterman R, van der Leun J, Rath J (1999) Mixed embeddedness: (In)formal economic activities and immigrant businesses in the Netherlands. International Journal of Urban and Regional Research 23(2):252-266

Larner W (2006) Brokering citizenship claims: Neo-liberalism, biculturalism and multiculturalism in Aotearoa/New Zealand. In Tastsoglou E and Dobrowolsky A (eds) Women, migration and citizenship: Making local, national and transnational connections, Ashgate, Burlington, VT, pp 131-148

Lewin J, Meares C, Cain T, Spoonley P, Peace R, Ho E (2011) Namasté New Zealand: Indian employers and employees in Auckland. Massey University/University of Waikato, Auckland

Lewis N, Lewis O, Underhill-Sem Y (2009) Filling hollowed out spaces with localised meanings, practices and hope: Progressive neoliberal spaces in Te Rarawa. Asia Pacific Viewpoint 50(2):166-184

Lewis N (2009) Progressive spaces of neoliberalism? Asia Pacific Viewpoint 50(2):113-119

Meares C, Cain T, Spoonley P (2011) Bamboo networks: Chinese business owners and co-ethnic networks in Auckland, New Zealand. Journal of Overseas Chinese 7:258-269

Meares C, Ho E, Peace R, Spoonley P (2010a) Bamboo networks: Chinese employers and employees in Auckland. Massey University/University of Waikato, Auckland

Meares C, Ho E, Peace R, Spoonley P (2010b) Kimchi networks: Korean employers and employees in Auckland. Massey University/University of Waikato, Auckland

Meares C, Lewin J, Cain T, Spoonley P, Peace R, Ho E (2011) Bakkie, braai and boerewors: South African employers and employees in Auckland and Hamilton. Massey University/University of Waikato, Auckland

Ministry of Economic Development (2011) SMEs in New Zealand: Structure and dynamics 2011. Ministry of Economic Development, Wellington 
Pang CL, Rath J (2007) The force of regulation in the land of the free: The persistence of Chinatown, Washington DC as a symbolic ethnic enclave. In Ruef M, Lounsbury M (eds) The sociology of entrepreneurship: Research in the sociology of organizations, Emerald Group Publishing Limited, Amsterdam, pp 191-216

Pernice R, Trlin A, Henderson A, North N, Skinner M (2009) Employment status, duration of residence and mental health among skilled migrants to New Zealand: Results of a longitudinal study. International Journal of Social Psychiatry 55(3):272-287, doi: $10.1177 / 0020764008093685$

Portes A (1998) Social capital: Its origins and applications in modern sociology. Annual Review of Sociology 24:1-24

Rath J (2002) Needle games: A discussion of mixed embeddedness. In J. Rath (ed) Unravelling the Rag Trade: Immigrant Entrepreneurship in Seven World Cities, Berg, Oxford, pp 1-27

Skilling G (2010) The construction and use of national identity in contemporary New Zealand political discourse. Australian Journal of Political Science 45(2):175-189

Skilling P (2005) National identity and immigration: Contemporary discourses. New Zealand Sociology 20(2):98-120

Spoonley P, Meares C (2011) Laissez-faire multiculturalism and relational embeddedness: Ethnic precincts in Auckland. Cosmopolitan Civil Societies Journal 3(1):42-64

Spoonley P, (2003) The contemporary political economy of labour migration in New Zealand. Paper read at Annual Sociological Association of Aotearoa, New Zealand Conference, at Auckland University of Technology

Spoonley P, Bedford R (2012) Welcome to our world? Immigration and the reshaping of New Zealand. Dunmore Publishing, Auckland

Spoonley P, Butcher A (2009) Reporting superdiversity: The mass media and immigration in New Zealand. Journal of Intercultural Studies 30(4):355-372

Statistics New Zealand (2010) Longitudinal Immigration Survey: New Zealand - Wave 3. Statistics New Zealand, Wellington

Stillman S, Maré DC (2009) The labour market adjustment of immigrants in New Zealand, Motu Working Paper. Motu Economic and Public Policy Research, Wellington

Vertovec S (2003) Migration and other modes of transnationalism: Towards conceptual crossfertilization. International Migration Review 37(3):641-665. doi: 10.2307/30037752

Vertovec S (2009) Transnationalism. Routledge, London and New York

Waldinger R, Ward R, Aldrich HE (1990) Ethnic entrepreneurs: Immigrant business in industrial societies. Sage Publications, Newbury Park, London and New Delhi

Watson B, Meares C, Spoonley P, Cain T, Peace R, Ho E (2011) Bangers ' $n$ ' mash: British employers and employees in Auckland and Hamilton. Massey University/University of Waikato, Auckland

Wong LL, Ng M (2002) The emergence of small transnational enterprise in Vancouver: The case of Chinese entrepreneur immigrants. International Journal of Urban and Regional Research 26(3):508-530 